\title{
Shrimp by-catch reduction using a short funnel net, in the Gulf of Tehuantepec, South Pacific, Mexico
}

\author{
Saúl Sarmiento-Náfate ${ }^{1}$, Heldail A. Gil-López ${ }^{1} \&$ Daisy Arroyo ${ }^{2}$ \\ 1 Dirección General de investigación Pesquera en el Pacífico Sur, Instituto Nacional de la Pesca, C.P. 70680 Salina \\ Cruz, Oaxaca, México; nafatess@yahoo.com.mx \\ 2 Centro de Investigación en Ciencias del Mar y Limnología (CIMAR), y Escuela de Biología, Universidad de Costa \\ Rica, Apdo. Postal 2060, San Pedro de Montes de Oca, San José, Costa Rica; daisy@biologia.ucr.ac.cr
}

Received 17-XI-2003. Corrected 26-I-2007. Accepted 11-IV-2007.

\begin{abstract}
Reduction of the by-catch in shrimp fishery is an important goal worldwide. In order to compare bycatch using the conventional trawling net and a newly designed short funnel net, nine cruises were carried out by the commercial fleet operating in the Gulf of Tehuantepec, Mexico. A total of 480 trawls were done (mean duration: $85 \mathrm{~min}$ ). The experimental trawls using the modified net produced a $21.13-28.86 \%$ by-catch reduction (confidence interval $95 \%$ ), a $3 \%$ increase of shrimp catch, and a significant reduction on net recovery time. Rev. Biol. Trop. 55 (3-4): 889-897. Epub 2007 December, 28.
\end{abstract}

Key words: Shrimp trawling, by-catch, new net design.

Shrimp trawling fishery in the México started in 1927 (Ferreira 1965, Igartua 1992) and development in fishing techniques and gear structure has not been constant. At the beginning and until the decade of 1950, ships were equipped with wing and "corua" trawling nets (Sarmiento and Gil 1995). Later, former trawl nets were replaced by new American designs, mainly because these were simpler and easier to handle, and a substantial increase of their fishing efficiency was observed.

Some years later, Ercoli (1989) developed a selective device denominated DISELA, in order to reduce incidental catch of hake in the prawn fishery in Argentina; the device was incorporated in a 180 feet net size of mouth. Results of those experimental cruises indicated that when installed to the net, the excluder produced a $70 \%$ escape of hake, and although an $18 \%$ loss of prawn was observed, the device did not affect the size composition of the prawn catch. Afterwards, Conolly (1992) in
Brazil modified the shape of the traditional net by reducing the original length from $20.1 \mathrm{~m}$ to $11.25 \mathrm{~m}$, to compare the differences of shrimp accompanying fauna (SAF) of both trawl nets within the commercial fleet. More recently, Sarmiento (1993) proposed a double shrimp net of $11.43 \mathrm{~cm}\left(4 \frac{1}{2}\right.$ ") mesh size, these overlapped nets conformed a $5.71 \mathrm{~cm}\left(2 \frac{1}{4} 4^{\prime \prime}\right)$ mesh size. Later on, various attempts regarding trawling system improvement for shrimp capture were carried out by countries like Canada and United States among others, while scarce technical innovations were done in Mexico.

In spite of the improvements developed until now, the incidental catch of non-target species is one of the most worrying problems that shrimp fishing faces, it is particularly important in tropical areas where shrimp by-catches are high and an important amount is discarded.

Because of the importance of a sustainable use of marine resources, a traditional trawl and a modified trawl were tested in the Gulf 
of Tehuantepec, Mexico, in order to assess efficiency on by-catch reduction in shrimp trawling; cruises were carried out during commercial and shrimp ban seasons.

\section{MATERIALS AND METHODS}

Study area description: The Gulf of Tehuantepec is the most important fishing area in Mexico's southern Pacific and corresponds to the traditional shrimp fishing grounds for Oaxaca and Chiapas commercial fleets with a continental shelf of approximately $5988 \mathrm{~km}^{2}$ (Sepúlveda \& Soto 1987). The Gulf extends from Punta Chipehua, $8 \mathrm{~km}$ West from Salina Cruz Port, in Oaxaca State, to Puerto Madero, Chiapas (16 $00^{\prime}$ $\left.-14^{\circ} 42^{\prime} \mathrm{N}, 95^{\circ} 25^{\prime}-92^{\circ} 30^{\prime} \mathrm{W}\right)$.

The Gulf's geological origin is based on the tectonic activity generated by the interaction between the Cocos and Caribbean plates. Geologically, it is conformed by detritus of terrigenous material from metamorphic and plutonic rocks that are continuously eroded, and have the ocean as final destiny (CarranzaEdwards et al. 1998). The marine floor texture distribution of silts are composed principally by muddy sands, sandy-muds and muds (Carranza-
Edwards 1987). The most important lithologic groups on the coastal zone are silts and sedimentary rocks of different ages, intermediate and basic volcanic rocks, plutonic and metamorphic rocks (Padilla and Sánchez 1983).

The Gulf of Tehuantepec is influenced by northern winds, as well as tropical storms, quasi-biannual Pacific oscillation and in a higher degree by "El Niño" phenomenon (Hurd 1929). According to Köppen (modified by Garcia 1981), the region type corresponds to a humid warm climate (Monreal-Gomez and Salas de León 1998), with summer rainy season and presence of midsummer isotherm, and an annual temperature that corresponds to the Ganges type (Anonymous 1988).

Fleet characteristics: The experimental cruises were carried out onboard commercial trawlers of the shrimp fleet that operates in the Gulf of Tehuantepec, having as disembarking ports Salina Cruz in Oaxaca State and Puerto Madero in Chiapas. Technical characteristics of ships used for the experimental cruises are listed in Table 1.

Description of fishing gears: Modification of fishing gears were applied for two trawl net

TABLE 1

Characteristics of shrimp fleet experimental units

$\begin{array}{lcccccccc}\text { Vessel } & \text { Year } & \mathrm{L}(\mathrm{m}) & \mathrm{W}(\mathrm{m}) & \mathrm{D}(\mathrm{m}) & \mathrm{Hp} * & \mathrm{GTR} * & \text { NTR* } & \text { Hull material } \\ \text { F/V 1 } & 1982 & 20.26 & 6.60 & 3.60 & 375 & 123.24 & 73.24 & \text { Steel } \\ \text { F/V 2 } & 1974 & 21.60 & 6.00 & 3.26 & 365 & 93.82 & 28.96 & \text { Steel } \\ \text { F/V 3 } & 1964 & 21.00 & 5.40 & 4.20 & 170 & 96.01 & 62.28 & \text { Steel } \\ \text { F/V 4 } & 1980 & 21.00 & 6.00 & 3.35 & 365 & 115.64 & 62.95 & \text { Steel } \\ \text { F/V 5 } & 1976 & 21.00 & 6.79 & 3.35 & 365 & 96.96 & 62.08 & \text { Steel } \\ \text { F/V 6 } & 1966 & 21.30 & 6.16 & 3.10 & 370 & 113.34 & 84.73 & \text { Steel } \\ \text { F/V 7 } & 1971 & 19.80 & 5.41 & 3.60 & 380 & 65.00 & 32.50 & \text { Steel } \\ \text { F/V 8 } & 1974 & 21.60 & 6.00 & 3.26 & 375 & 93.82 & 28.96 & \text { Steel } \\ \text { F/V 9 } & 1972 & 22.87 & 6.10 & 3.45 & 380 & 100.01 & 65.37 & \text { Steel }\end{array}$

*(L= Length; $\mathrm{W}=$ Width $\mathrm{D}=$ Draft; Hp= Horse power; GTR=Gross Tonnage Record; NTR = Net Tonnage Record $)$

Note. By mandate of the Federal Law for Transparency and Access to Government Public Information, names of fishing vessels participating in any research conducted under government endorsement are confidential. 
designs: Volador (Flyer) type, which is used by $70 \%$ of the fleet operating in the Gulf of Tehuantepec (Sarmiento-Náfate and Gil-López 1998) and the Cholo type, which was only used in one cruise. Netting materials used to built both trawls were polyamide (PA) multifilament dye and treated, twine \#18 and diameter of 1.6 $\mathrm{mm}$, mesh size $4.44 \mathrm{~cm}(13 / 4 ")$ and $5.08 \mathrm{~cm}$ (2"); whereas the codend was made of the same PA and $3.81 \mathrm{~cm}\left(1 \frac{112 ")}{2}\right.$ mesh size.

Net was modified by making all bars tapping along lateral edges of upper and lower panels, in order to reduce the length of the funnel on approximately $49 \%$ of the normal length. The reduction was determined by the net size, and by the array of the sections (regarding dimensions of side panels, as well as upper and lower panels length). These characteristics may vary from one net to another, although upper panel may have the same length. Changes in the Volador net were made inside, upper and lower panels, resulting in a general decrease of length funnel, particularly in the last section before the codend.

The whole trawling system was rigged according to skipper's skill and experience. Characteristics of experimental nets used in the cruises regarding type, size and mesh size, are listed in Table 2. Modifications were based on the concept of fish behavior. Fish will escape using its lateral muscles, that would enable

TABLE 2

Net characteristics by type for experimental trials

$\begin{array}{lccc}\text { Vessel } & \text { Net type } & \text { Net size (m) } & \text { Mesh size (mm) } \\ \text { F/V 1 } & \text { Volador } & 24.4\left(80^{\prime}\right) & 44.45 \\ \text { F/V 2 } & \text { Volador } & 24.4\left(80^{\prime}\right) & 44.45 \\ \text { F/V 3 } & \text { Volador } & 22.9\left(75^{\prime}\right) & 44.45 \\ \text { F/V 4 } & \text { Volador } & 24.4\left(80^{\prime}\right) & 44.45 \\ \text { F/V 5 } & \text { Volador } & 24.4\left(80^{\prime}\right) & 44.45 \\ \text { F/V 6 } & \text { Volador } & 24.4\left(80^{\prime}\right) & 44.45 \\ \text { F/V 7 } & \text { Volador } & 22.9\left(75^{\prime}\right) & 44.45 \\ \text { F/V 8 } & \text { Volador } & 24.4\left(80^{\prime}\right) & 44.45 \\ \text { F/V 9 } & \text { Volador } & 24.4\left(80^{\prime}\right) & 44.45\end{array}$

them to slip from the original $11.43 \mathrm{~cm} \mathrm{(4}$ $1 / 2$ ") mesh. Nevertheless, as the target species, shrimp will be caught, since there is a significant difference on fish and shrimp locomotion patterns. In this study is also assumed that shrimp by-catch obtained by the conventional net represents the unit, this means, it will be the unit of measure between the conventional and modified nets, and therefore, the difference found is given in these terms.

Experimental cruises: The cruises took place both during fishing and shrimp ban seasons of 1998 and 1999. Paired trawls were done on outrigger traditional trawlers; the modified experimental net was placed at starboard and control net at port side, as shown in Fig. 1 (to avoid bias, nets were switched after a number of sets). Catch obtained from each net was separated by a wooden gate to enable an adequate classification and quantification of the catch. Trawl sets were done within a range of 10.92$69.2 \mathrm{~m}$ depth along the fishing grounds of the Gulf of Tehuantepec. Trawling time varied from 32 up to $360 \mathrm{~min}$, with an average of 85 min (mode of $60 \mathrm{~min}$ ). For each trawl set, initial and final geographical data position (GPS Magellan DLX 5000) was registered, as well as total fishing time and depth (videosounder Furuno FVC 668).

Data analysis: Catch volumes were compared using frequency histograms and descriptive statistics, which provided reliable assessment to identify the most adequate analysis for the information to be processed. Variance Analysis Test was applied to shrimp and by-catch to establish if catches of both nets were statistically different with a significance level of 0.05 , under the following hypothesis:

Ho $=$ Differences between shrimp and by-catch in traditional and modified nets are originated randomly.

Ha $=$ Differences between shrimp and by-catch in traditional and modified nets are derived from modifications made to the experimental net. 


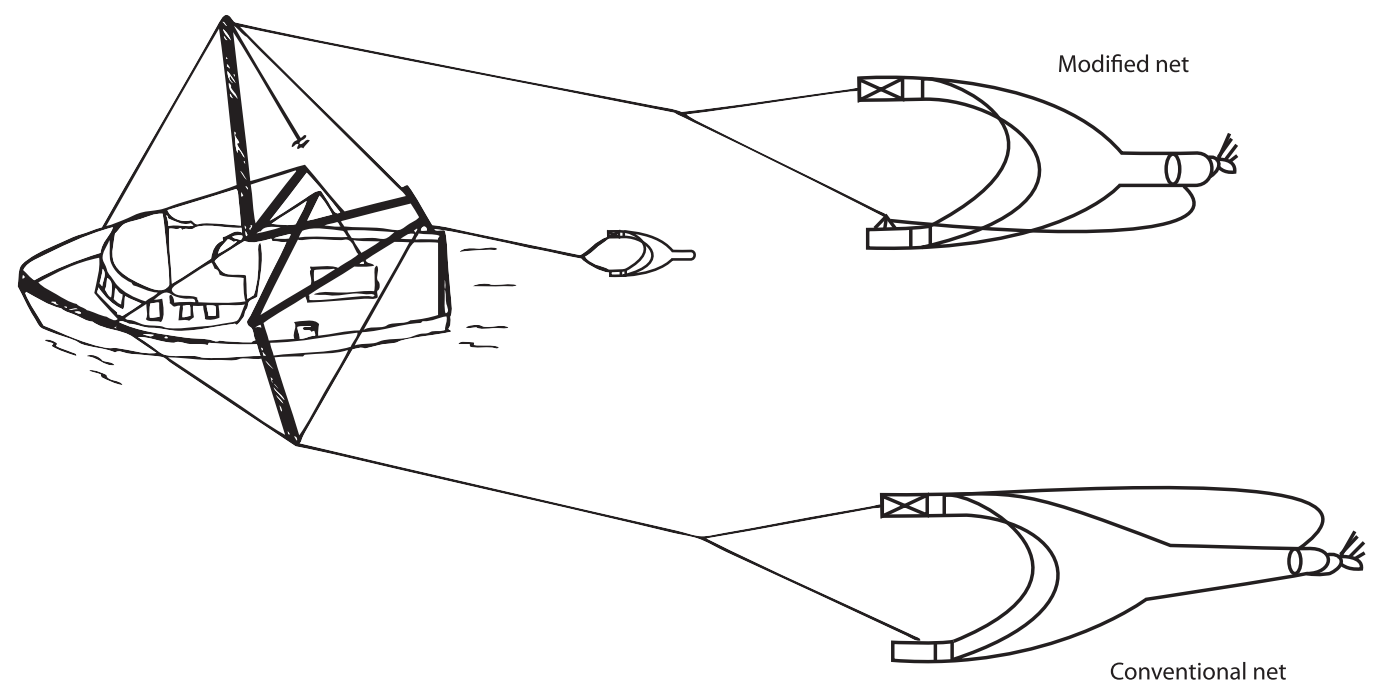

Fig. 1. Rigging of trawling nets in the experimental cruises.

\section{RESULTS}

Statistical tests were applied to shrimp catches and by-catch data, in order to determine significant statistical differences between conventional and modified fishing gears (short tunnel net). The analysis of variance of by-catch data from both conventional and modified nets, is significant $(\mathrm{F}=11.94, \mathrm{p}<0.05)$, indicating that the modification of the fishing gear reduces substantially the by-catch of diverse species and for different sizes. Nevertheless, in spite of the different values obtained, no statistical differences were observed from shrimp catch results $(\mathrm{F}=0.0005, \mathrm{p}<0.05)$.

A total of 480 paired trawl sets were made during nine experimental cruises, using both conventional and modified nets. Total trawling time was equivalent to $483.4 \mathrm{~h}$.

Total catch was $95213.8 \mathrm{~kg}, 3.31 \%$ correspond to shrimp and $96.69 \%$ to by-catch. Total by-catch from both nets were $92061 \mathrm{~kg}$, from which $55.75 \%(51315 \mathrm{~kg})$ was for the conventional net and $44.25 \%$ (40 $746 \mathrm{~kg}$ ) for the experimental net. This resulted in a $21 \%$ of by-catch reduction for the modified net.

As for by-catch composition of each net, Table 3 shows the incidence of species with a description of their commercial importance. In the list it is evident the absence of barracuda, silver corvina and the guitarfish on the modified net; whereas crabs, snails and shells, scorpionfish and devil ray don't appear when using the conventional net.

Shrimp by-catch composition: Shrimp by-catch species composition in the Gulf of Tehuantepec is diverse, some organisms being abundant. The catch composition during the study period reached up to 30 species of which $78 \%$ were fish, $6.5 \%$ rays, $6.5 \%$ crabs, $6.5 \%$ mollusks, $3 \%$ other organisms (species of fish for this frequency was very low) and a $3 \%$ composed mainly of plant material. From the total of species obtained as by-catch, only $10 \%$ were considered as fine commercial species, which are used for consumption onboard; second class fish is used for commercial purposes.

The most important by-catch species in terms of abundance was the sheepshead $(P$. axillaris) with an average frequency value of $22 \%$ in the conventional net and $20 \%$ in the modified net (Tables 4 and 5). The blue crab was another important species, representing 7 $\%$ and $13.6 \%$ of the catch by conventional and modified nets, respectively. The term "others" 
TABLE 3

Species abundance in control trawls for Conventional (CN) and Modified (MN) nets during the study

\begin{tabular}{|c|c|c|c|c|}
\hline Common name & Scientific name & $\mathrm{CN}$ & $\mathrm{MN}$ & Commercial sp. \\
\hline Croaker & Polydactilus approximans & $X$ & $\mathrm{X}$ & Yes \\
\hline Silvery drum & Larimus acclivis & $X$ & $X$ & Yes \\
\hline King fish & Micropogon altipinnis & $\mathrm{X}$ & $X$ & No \\
\hline Puffer & Sphoreoides annulatus & $\mathrm{X}$ & $\mathrm{X}$ & Yes \\
\hline Spur drum & Stellifer illecebrosus & $X$ & $\mathrm{X}$ & Yes \\
\hline Silver butterfish & Peprilus simillumus & $X$ & $\mathrm{X}$ & Yes \\
\hline Chapeta & Selene peruviana & $X$ & $X$ & Yes \\
\hline Sea catfish & Arius seemani & $\mathrm{X}$ & $\mathrm{X}$ & Yes \\
\hline Shorthead lizarfish & Synodus scituliceps & $\mathrm{X}$ & $\mathrm{X}$ & No \\
\hline Goatfish & Pseudopeneus grandisquamis & $\mathrm{X}$ & $\mathrm{X}$ & No \\
\hline Armed snook & Centropomus robalito & $\mathrm{X}$ & $\mathrm{X}$ & Yes \\
\hline Snapper & Lujanus peru & $\mathrm{X}$ & $\mathrm{X}$ & Yes \\
\hline Crab & Callinectes spp. & $\mathrm{X}$ & $\mathrm{X}$ & Yes \\
\hline Thoothed flounder & Cyclopseta querna & $\mathrm{X}$ & $\mathrm{X}$ & Yes \\
\hline Lucero & Diplectrum pacificum & $\mathrm{X}$ & $\mathrm{X}$ & No \\
\hline White mojarra & Diapterus peruvianus & $\mathrm{X}$ & $\mathrm{X}$ & Yes \\
\hline Mojarra & Eucinostomus entomelas & $\mathrm{X}$ & $\mathrm{X}$ & No \\
\hline Palmera & Chloroscombrus orqueta & $\mathrm{X}$ & $\mathrm{X}$ & No \\
\hline Bobo & Menticirrhus elongatus & $\mathrm{X}$ & $\mathrm{X}$ & Yes \\
\hline Ray & Rhinoptera steindachneri & $\mathrm{X}$ & $\mathrm{X}$ & Yes \\
\hline Sheepshead & Pomadasys axillaris & $\mathrm{X}$ & $\mathrm{X}$ & No \\
\hline Deepbody threadherring & Ophistonema libertate & $\mathrm{X}$ & $\mathrm{X}$ & No \\
\hline Searobin & Prionotus loxias & $X$ & $\mathrm{X}$ & No \\
\hline Threadfish & Chaetodipterus zonatus & $\mathrm{X}$ & $\mathrm{X}$ & No \\
\hline Barracuda & Sphyraena ensis & $\mathrm{X}$ & & No \\
\hline Silver drum & Elattarchus archidiun & $\mathrm{X}$ & & No \\
\hline Guitarfish & No identified & $\mathrm{X}$ & & No \\
\hline Bluecrab & Calappa convexa & & $\mathrm{X}$ & No \\
\hline Snail \& shells & Whitout name & & $\mathrm{X}$ & No \\
\hline Scorpionfish & Scorpaena russula & & $X$ & No \\
\hline Devil ray & Rhinobates glaucostigma & & $X$ & No \\
\hline Others & Whitout name & $X$ & $X$ & No \\
\hline Waste & Whitout name & $\mathrm{X}$ & $\mathrm{X}$ & No \\
\hline
\end{tabular}


TABLE 4

By-catch composition by percentage of species using the conventional net

\begin{tabular}{|c|c|c|c|}
\hline Common name & $\begin{array}{c}\text { Maximun } \\
\%\end{array}$ & $\begin{array}{c}\text { Minimun } \\
\%\end{array}$ & $\begin{array}{c}\text { Averag } \\
\%\end{array}$ \\
\hline Croaker & 25.25 & 15.21 & 17.60 \\
\hline Silvery drum & 5.10 & 1.50 & 3.90 \\
\hline King fish & 7.60 & 3.00 & 4.40 \\
\hline Spur drum & 10.50 & 3.40 & 6.30 \\
\hline Corvina & 4.10 & 1.60 & 2.95 \\
\hline Silver butterfish & 12.80 & 1.50 & 5.45 \\
\hline Chapeta & 17.90 & 2.25 & 10.15 \\
\hline Sea catfish & 6.30 & 1.50 & 4.40 \\
\hline Armed snook & 8.10 & 0.75 & 4.10 \\
\hline Blue Crab & 12.60 & 2.15 & 7.00 \\
\hline Toothed flounder & 24.50 & 1.60 & 6.25 \\
\hline White mojarra & 18.25 & 1.50 & 9.80 \\
\hline Mojarra & 15.50 & 1.15 & 8.40 \\
\hline Mojarra charra & 26.35 & 0.70 & 9.95 \\
\hline Bobo & 2.55 & 2.00 & 2.30 \\
\hline Ray & 17.30 & 1.00 & 8.90 \\
\hline Sheepshead & 45.40 & 4.05 & 22.15 \\
\hline Sardine & 3.00 & 1.70 & 2.40 \\
\hline Searobin & 7.20 & 2.10 & 3.90 \\
\hline Threadfish & 11.90 & 3.05 & 5.90 \\
\hline Snapper & 11.35 & 2.15 & 6.75 \\
\hline Lucero & 4.30 & 2.15 & 3.20 \\
\hline Puffer & 4.25 & 0.80 & 2.50 \\
\hline Others & 9.32 & 3.15 & 5.30 \\
\hline Waste & 15.75 & 2.30 & 8.50 \\
\hline Barracuda & 2.02 & 2.02 & 2.02 \\
\hline Guitarfish & 4.32 & 4.32 & 4.32 \\
\hline Shortthead Lizardfish & 6.38 & 6.38 & 6.38 \\
\hline Goatfish & 7.75 & 7.75 & 7.75 \\
\hline
\end{tabular}

TABLE 5

Estimated values of by-catch composition by percentage of species using the modified net

\begin{tabular}{|c|c|c|c|}
\hline Common name & $\begin{array}{c}\text { Maximun } \\
\%\end{array}$ & $\begin{array}{c}\text { Minimun } \\
\%\end{array}$ & $\begin{array}{c}\text { Average } \\
\%\end{array}$ \\
\hline Croaker & 21.00 & 1.50 & 8.00 \\
\hline Silvery drum & 7.00 & 1.20 & 4.00 \\
\hline King fish & 10.00 & 4.00 & 6.65 \\
\hline Puffer & 1.50 & 1.50 & 1.50 \\
\hline Blue crab & 19.50 & 19.50 & 19.50 \\
\hline Snail and shells & 2.25 & 2.25 & 2.25 \\
\hline Spur drum & 4.10 & 3.00 & 3.50 \\
\hline Silver butterfish & 2.25 & 2.25 & 2.25 \\
\hline Chapeta & 18.50 & 3.00 & 10.10 \\
\hline Sea catfish & 6.75 & 5.50 & 6.25 \\
\hline Shorthead Lizardfish & 7.50 & 7.50 & 7.50 \\
\hline Goatfish & 6.90 & 2.25 & 4.60 \\
\hline Armed snook & 10.00 & 2.50 & 6.25 \\
\hline Devil ray & 2.90 & 2.90 & 2.90 \\
\hline Snapper & 6.90 & 5.20 & 6.10 \\
\hline Blue Crab & 46.60 & 2.25 & 13.60 \\
\hline Toothed flounder & 18.30 & 3.00 & 8.50 \\
\hline Lucero & 1.50 & 1.50 & 1.50 \\
\hline Scorpionfish & 11.70 & 11.70 & 11.60 \\
\hline Hite mojarra & 20.00 & 2.90 & 11.05 \\
\hline Mojarra & 16.70 & 3.60 & 8.25 \\
\hline Palmera & 16.70 & 2.25 & 7.25 \\
\hline Bobo & 8.40 & 2.15 & 5.30 \\
\hline Ray & 23.00 & 0.75 & 11.30 \\
\hline Sheepshead & 35.00 & 5.00 & 20.00 \\
\hline Sardine & 4.30 & 1.50 & 2.90 \\
\hline Searobin & 7.70 & 5.00 & 6.30 \\
\hline Threadfish & 7.20 & 1.40 & 3.80 \\
\hline Others & 9.20 & 2.00 & 4.80 \\
\hline Waste & 4.50 & 2.00 & 3.50 \\
\hline
\end{tabular}


in the species list, refers to species represented by a single specimen of small size, and included the following species: mullet, catarina, barracuda and tonguefish. Note that all the species referred in Tables 4 and 5 are the most usually obtained as by-catch fauna in shrimp fishery in the Gulf of Tehuantepec.

Data analysis indicated that both trawl nets catch the same species, however, their volumes varied. While the volume of chapeta, mojarra, sardine, silvery drum and snapper, was the same for both fishing nets, the volume of armed snook, bobo, crab, king fish, ray, searobin and toothed flounder, slightly increased with the modified net. Besides, the catch volume of croaker, goatfish, lucero, puffer, sea catfish, sheepshead, shorthead lizardfish, silver butterfish, spur drum, threadfish, white mojarra and others, was observed to be reduced when using the modified net (Tables 4 and 5).

\section{By-catch with the conventional shrimp}

trawl: By-catch with the conventional shrimp trawl varied from $0 \mathrm{~kg}$ up to $1200 \mathrm{~kg}$ per set, with a mean value of $106.9 \mathrm{~kg}$ ( $96.86 \mathrm{~kg}$ to $119.94 \mathrm{~kg}$, with a confidence level of $95 \%$ ) and a median of $90 \mathrm{~kg}$. The most frequent ranges observed were between $0-100 \mathrm{~kg}$, that represented the $60.2 \%$ of all trawls (289 trawls) carried out with this net; the second most frequent range found was $100-200 \mathrm{~kg}$, with a $32.29 \%$ of the total trawls (155 trawls). Table 4 also lists maximum, minimum and average values for the species captured with the conventional net. Values are given in percentages and they represent the proportion of the by-catch in general terms.

By-catch with the modified shrimp trawl (Short Funnel Net): By-catch with the modified net varied from $0 \mathrm{~kg}$ to $850 \mathrm{~kg}$ per set, with an average value of $84.8 \mathrm{~kg}$ ( 77.40 $\mathrm{kg}$ to $92.37 \mathrm{~kg}$, with a confidence level of 95 $\%$ ) and a median of $70 \mathrm{~kg}$. The most frequent range was $0-100 \mathrm{~kg}$ representing $75.62 \%$ of the total trawls (367 trawls). The second most frequent range observed was $100-200 \mathrm{~kg}$, representing the $19.58 \%$ of trawls (94 trawls). The maximum, minimum and average values for the captured group of species with the modified net are detailed in Table 5.

By-catch reduction: A reduction from $15 \%$ to $50 \%$ of the by-catch component, was observed when using the modified fishing trawl at different depth strata. In this study, the largest number of trawls (50\% of total trawls), were carried out from 10 to $20 \mathrm{~m}$ deep, followed by those between 21 and $30 \mathrm{~m}$.

Shrimp catch: Shrimps captured were mostly composed by white (Litopenaeus vannamei), brown (Farfantepenaeus aztecus), blue (Litopenaeus stylirostris) and red shrimp (Farfantepenaeus brevirostris), with sizes from $80 \mathrm{~mm}$ to $220 \mathrm{~mm}$ of total length. The total catch of shrimp with both trawl nets was of 49 $\%$ and $51 \%$ for the conventional and the modified gears respectively. In this study the shrimp volumes obtained with both nets were not statistically different by the ANOVA test applied; however, a slightly higher shrimp catch was observed with the modified net (3\%).

Regarding shrimp catches using the conventional net, they varied from 0 up to $26 \mathrm{~kg}$, being the most frequent range 0 to $5 \mathrm{~kg}$, with a value of $60 \%$ (288 trawls), and the second ranged from 5 to $10 \mathrm{~kg}$, with a value of 22.7 $\%$ (109 trawls).In the case of the modified net, catch variation ranged from 0 up to $26.2 \mathrm{~kg}$, where the most frequent capture range was from 0 to $5 \mathrm{~kg}$, representing the $62 \%$ (299) of the total trawls; whereas the second range observed was between 5 and $10 \mathrm{~kg}$, which represented $19.4 \%$ (93) of the trawls.

\section{DISCUSSION}

In many world shrimp fisheries the underutilized by-catch component represents almost $96 \%$ of the total capture. Alternatives to reduce this accompanying fauna, are proposed in this paper and in previuos studies (SarmientoNáfate and Gil-López 1998), such as the increase of mesh size from $3.81 \mathrm{~cm}\left(\begin{array}{ll}1 & 1 / 2\end{array}\right.$ 
to $4.12 \mathrm{~cm}(15 / 8$ ") in the codend, in order to allow the escape of juvenile fish caught during trawls. Among most fish groups, lateral muscles are used for movement, feeding, migration and escape; when caught in the net, the fish reaction results in a higher degree of movement when compared to shrimp (Okonski and Martini 1976). The behavior pattern described, becomes more evident in threatening circumstances, having more varied reactions, depending on the species, and even on the situation. With a trawling net, small fish have few escape possibilities, as the operation of the net is faster than its locomotion speed, being then captured in the net, whereas bigger fish may succeed in the escape process (Boddeke 1970). Taking this into consideration, one could conclude that reducing the size of the trawling shrimp net will cause a higher possibility of fish to escape, and reduce some of the by-catch fish species, as was observed in this study. Even thought, a $3 \%$ higher volume on shrimp catch was observed when using the modified net, more studies should be developed in order to confirm this result as to be completely related to the modification of the fishing gear. However, is very important to state that in terms of output, the modified gear won't cause a decrease of shrimp catch and therefore, it won't be an economical hazard to the activity; on the contrary, it may represent an increase of economic income as it is the target specie, and also a better shrimp quality.

From the results obtained, it is evident that the trawling fishing gears generate different effects due to the extraction of a varied number of fish and shellfish species that are, most of the time, discarded with the subsequent biodiversity disturbance. The new device decreased the by-catch component, and increased the shrimp one.

The modification of the fishing gear (short funnel trawl net) represented not only a bycatch reduction, but also may be interpreted as possible energy savings, since the less netting material used for the construction of the modified trawl (consequently less netting working area), may generate a smaller trawling resistance, thus may cause a reduction in fuel consumption; however this objective was not directly quantified in this study. Nevertheless, there are obvious economic savings, since there is a reduction of netting materials for construction of the modified trawl, increased quality of shrimp and time decrease on trawl recovery and discharge of the catch.

As further information, authors of this study carried out some other tests in the trawling section of the capture system using a double rigged foot rope, and despite the observed results were not the expected, this alternative migth be feasible, and the observed volumes of by-catch escape increased. Is possible that the use of double rigged foot rope in the fishing gear may favour by $60 \%$ the bycatch escape, however, this possibility requires further research.

The principal conclusions of this study remark the importance on the reduction of the body of shrimp trawl nets, as a feasible alternative to reduce by-catch. Secondly, that an increase in the mesh size of the codend from $3.81 \mathrm{~cm}\left(1 \frac{1}{2} "\right)$ to $4.12 \mathrm{~cm}(15 / 8 ")$, allows juvenile fish to escape, without -shrimp losses, and finally, the possibility to experience the double foot rope in shrimp trawling net, aiming to increase volumes of by-catch escapes.

\section{ACKNOWLEDGMENTS}

The authors are grateful to the Authorities of the Dirección General de Investigación Pesquera en el Pacífico Sur (DGIPPS) in Salina Cruz, Oaxaca, the vessel owners and all participating crews of the shrimp fleet of the Gulf of Tehuantepec, for their kind attention and multiple coordination efforts that made this research possible.

\section{RESUMEN}

La reducción de la fauna de acompañamiento del camarón (FAC) es uno de los temas de discusión más 
importantes en la pesca mundial. Con la finalidad de contribuir en este tópico, se diseñó y utilizó una red de arrastre variando la longitud del túnel, y se comparó su efecto con el de una red tradicional; durante 9 cruceros de la flota comercial en el Golfo de Tehuantepec, México. Se realizó un total de 480 lances con promedio de 85 min cada uno. Los arrastres de la red modificada mostraron mejores resultados, con variación entre 21.13 a $28.86 \%$, con un $95 \%$ de confianza de reducción de FAC, un incremento de $3 \%$ en la captura de camarón, y una disminución del tiempo de recuperación, lo que sugiere un incremento en la eficiencia gracias al nuevo diseño.

Palabras clave: arrastre de camarón, captura incidental, diseño de red, FAC.

\section{REFERENCES}

Anonymous. 1988. Compendio de estudios oceanográficos. Secretaria de Marina, Mexico D.F., Mexico.

Boddeke, R. 1970. By-catch reduction of Penaeid shrimp trawlers on basis of European experiences. Netherlands Institute for Fisheries Research (RIVO. DLO), I.J. Muiden, The Netherlands.

Carranza-Edwards, A. 1987. Investigación sobre el origen, proceso y distribución de minerales en el piso oceánico del Océano Pacífico Mexicano. Instituto de Ciencias del Mar y Limnología. UNAM, Mexico D.F., Mexico.

Carranza Edwards, A., E. Morales de la Garza \& L. Rosales Hoz. Tectónica, sedimentología y geoquímica, p. 1-12. In M. Tapia-García (ed.). El Golfo de Tehuantepec: el ecosistema y sus recursos. Universidad Autónoma Metropolitana, Iztapalapa, Mexico D.F., Mexico.

Conolly, C.P. 1992. By-catch activities in Brazil. Brazilian National Environment Research Center. International Conference on shrimp by-catch. Lake Good View, Florida, USA.

Ercoli, R. 1989. Dispositivo de Selectividad de langostino (DISELA). Boletín informativo del INIDEP, s.n., s.p., Buenos Aires, Argentina.

Ferreira, H. 1965. Notas sobre la historia de la pesquería comercial del camarón en el Pacífico de Mexico. INIBP, Serv. Div.x (99), Mexico D.F., Mexico.
García, E. 1981. Modificaciones al sistema de clasificación climática de Copen. Universidad Nacional Autónoma de Mexico, Mexico DF, Mexico.

Hurd, W.E. 1929. Northern of the Gulf of Tehuantepec. Mon. Weather Rev. 57: 192-194.

Igartua, L.E. 1992. Ensayo sobre la determinación de las dimensiones principales de una embarcación camaronera. Tesis de licenciatura, SEP-SEIT-DGEC y TM, ITMAR de Mazatlán, Mexico.

Monreal Gómez, M.A. \& D.A. Salas de León. 1998. Dinámica y estructura termohalina, p. 13-26. In M. Tapia-García (ed.). El Golfo de Tehuantepec: el ecosistema y sus recursos. Universidad Autónoma Metropolitana, Iztapalapa, Mexico D.F., Mexico.

Okonsky, S.L. \& L.W. Martini. 1976. Materiales didácticos para la capacitación en tecnología de artes y métodos de pesca. Serie de Materiales de Estudios en Ciencia y Tecnología del Mar. Secretaria de Educación Pública, Mexico D.F., Mexico.

Padilla y Sánchez, R.J., R.G. Martínez-Serrano \& V. TorresRodríguez. 1983. Carta Tectónica. Escala 1:2 000 000. Universidad Nacional Autónoma de Mexico (UNAM) e Instituto Nacional de Estadística, Geografía e Informática (INEGI), Mexico D.F., Mexico.

Sarmiento-Náfate, S. 1993. Análisis de la flota camaronera del Golfo de Tehuantepec y propuesta de una red prototipo. Tesis de Licenciatura, UAN-ESIP, San Blas, Nayarit, Mexico.

Sarmiento-Náfate, S. \& H.A. Gil-López. 1995. Diagnosis de la flota camaronera, p. 197-208. In M. TapiaGarcía (ed.). El Golfo de Tehuantepec: el ecosistema y sus recursos. Universidad Autónoma Metropolitana, Iztapalapa, Mexico D.F., Mexico.

Sarmiento-Náfate, S. \& H.A. Gil-López. 1998. Alternativas para reducir la fauna acompañante del camarón en el Golfo de Tehuantepec, Mexico. Reporte de Investigación INP-CRIP, Salina Cruz, Oaxaca, Mexico.

Sepúlveda, M.A. \& L.A Soto. 1987. Relación de la precipitación pluvial y la temperatura atmosférica sobre la producción de camarón en el Golfo de Tehuantepec Méx. Memorias Simp. VII Congreso Nal. Oceanografía Ensenada B.C. del 28 al 31 de julio 1987, Mexico. 
